Florida International University FIU Digital Commons

6-1985

\title{
Food and nutrition services in bone marrow transplant centers
}

Amy Dezenhall

Florida International University

DOI: $10.25148 /$ etd.FI14062260

Follow this and additional works at: https://digitalcommons.fiu.edu/etd

Part of the Dietetics and Clinical Nutrition Commons

\section{Recommended Citation}

Dezenhall, Amy, "Food and nutrition services in bone marrow transplant centers" (1985). FIU Electronic Theses and Dissertations. 2790. https://digitalcommons.fiu.edu/etd/2790

This work is brought to you for free and open access by the University Graduate School at FIU Digital Commons. It has been accepted for inclusion in FIU Electronic Theses and Dissertations by an authorized administrator of FIU Digital Commons. For more information, please contact dcc@fiu.edu. 
FOOD AND NUTRITION SERVICES

IN BONE MARROW TRANSPLANT CENTERS

by

Amy Dezenhall, R.D.

A thesis submitted in partial fulfillment of the requirements for the degree

MASTER OF SCIENCE

in the

Department of Dietetics and Nutrition

at

Florida International University

Approved:

Katharine Curry-Bartley,Ph.D.,R.D.

Professor

Thes is Committee Chairperson

Dietetics and Nutrition
Abdur R. Khan,M.D.,Ph.D., R.D. Associate Professor

Dietetics and Nutrition
Sara A. Blackburn, D.SC., R.D. Assistant Professor

Dietetics and Nutrition
Sergio De Lamerens, M.D.

Director, Division of Hematology/ Oncology, Miami Children's Hospital 


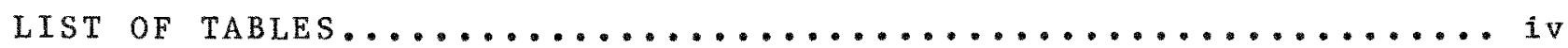

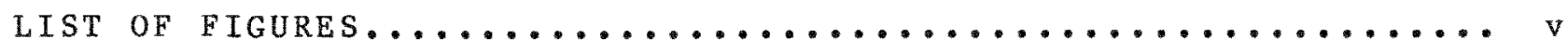
ACKNOWLEDGEMENTS..................................

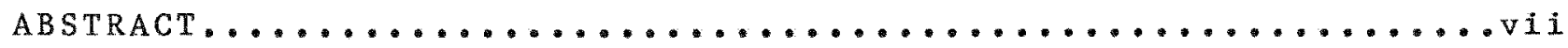
CHAPTER

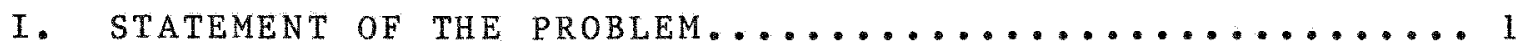

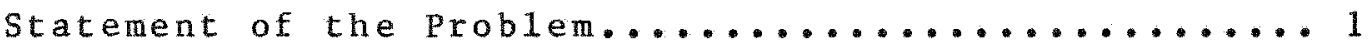

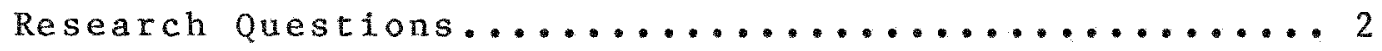

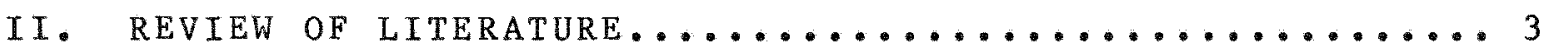

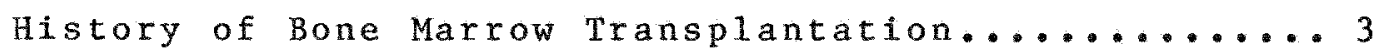

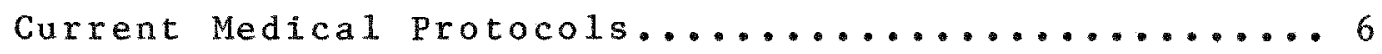

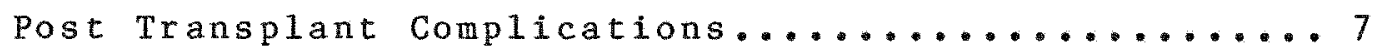

Nutritional Considerations of Bone Marrow Recipients.11

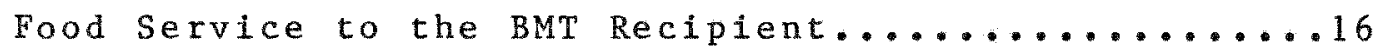

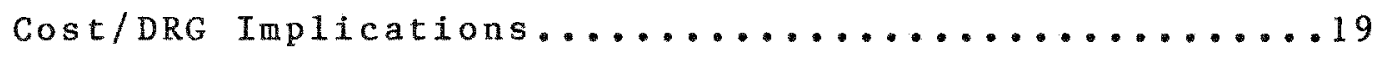

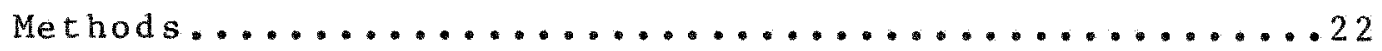

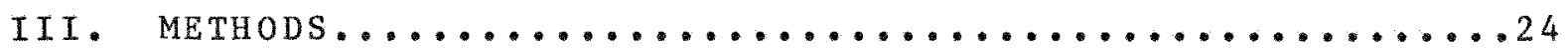

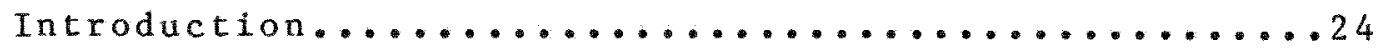

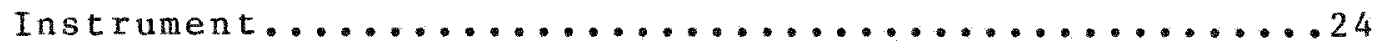

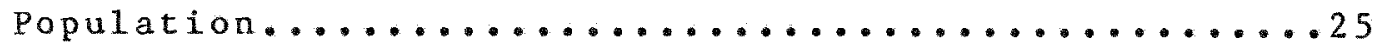

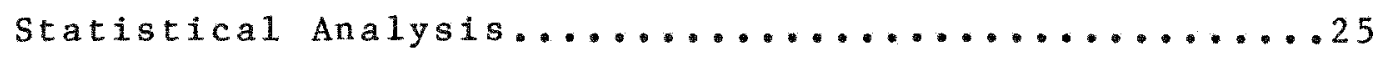

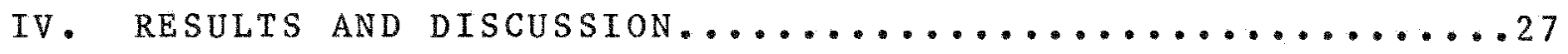

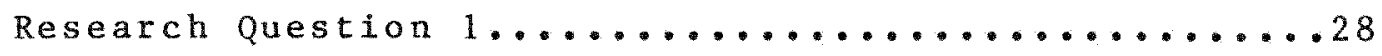

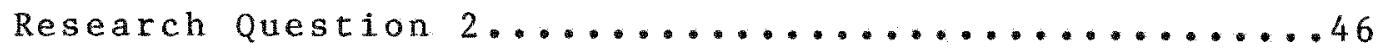

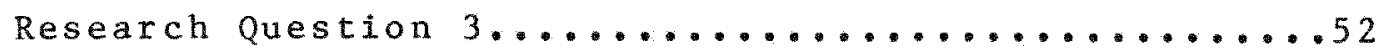

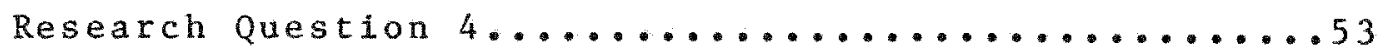




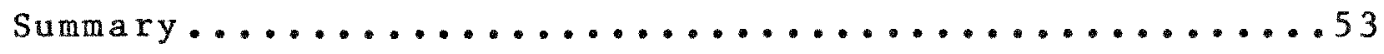

V. CONCLUSIONS ANd RECOMMENDATIONS.................... 55

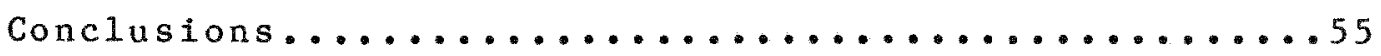

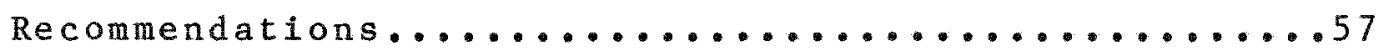

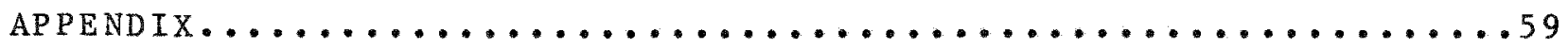

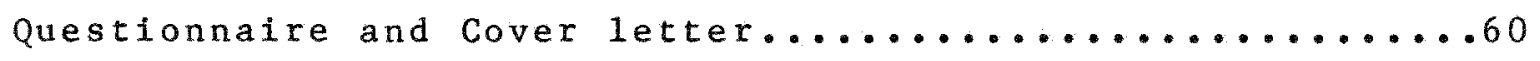

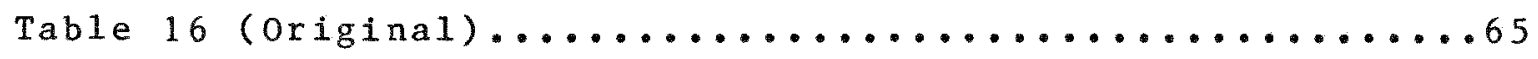

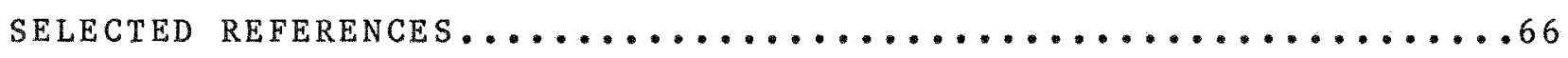


1. Nutritional Complications of

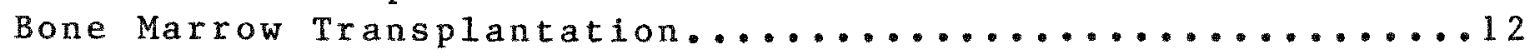

2. Medications that Impact Nutritional status................

3. Comparison of Dates BMT were First

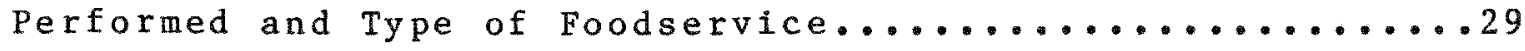

4. Problems During Development of Foodservice...............

5. Reasons for Changing from sterile Foodservice..............

6. Number of Beds and Type of Rooms in BMT Units.............33

7. Room Types and Diet Types in BMT Units....................

8. Number of Beds and Diet Types in BMT Units...............

9. Diet Type, Existence of Research

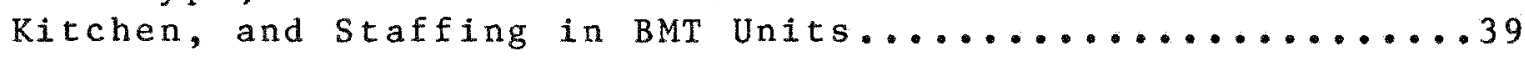

10. Foods Particularly Well-Accepted by

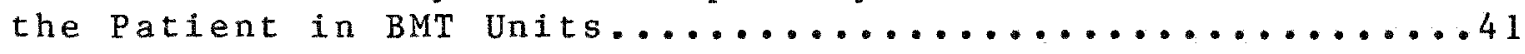

11. Diet Type, Hours of Food Delivery and

Existence of Food Weighing in BMT Units...............43

12. Diet Type and Average Length of

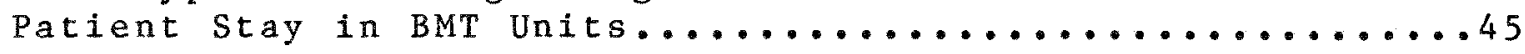

13. Number of Beds, Existence of Separate

FTE's and Scheduling of R.D.'s in BMT Units...........47

14. Type of Foodservice and Extent of

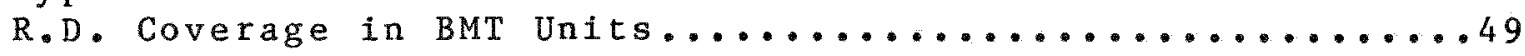

15. Incidence of R.D. Services in Various

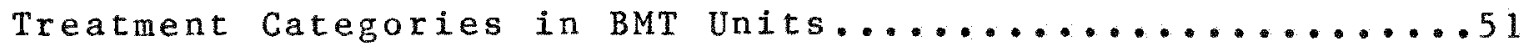




\section{LIST OF FIGURES}

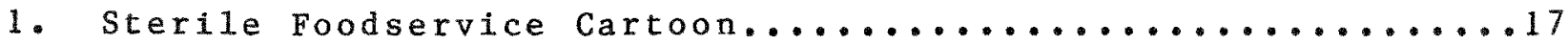




\section{ABSTRACT}

Nutritional support for bone marrow transplant recipients is recognized as vital, yet little research has occured to determine the best method.

This study was designed to survey existing food and nutrition services in bone marrow transplant centers in the U.S. in order to determine similarities in the services provided among centers from which a model protocol could be established for such centers.

A survey instrument was developed and sent to all chief dietitians associated with BMT centers in the U.S., listed by the International Bone Marrow registry, 1982. Items on the questionnaire included: background information on size and organization, nature of foodservice, and nutrition support services.

The research suggested that there was a trend away from sterile food service. Problems encountered in establishing the food and nutrition services included: availability of single-serve sterile foods, standardization of recipes, and palatability of autoclaved foods. Four centers switched from sterile diets to either low bacteria diets or modified house diets at some point 
in their operation. Patient related services of the registered dietitian were most concentrated on admission and during critical care monitoring. Nearly all respondents indicated a desire to form a network for developing standards for services provided.

Many differences between centers still remain which prevent the development of a model center. 


\section{CHAPTER I}

\section{STATEMENT OF THE PROBLEM}

This study was designed to survey existing food and nutrition services in bone marrow transplant centers in the United States. The purpose was to determine similarities in services provided from which a model protocol can be established for such centers.

Bone marrow transplantation (BMT) as a treatment for acute leukemia, aplastic anemia, and related blood disorders has progressed considerably over the past twenty years, and is a we11 accepted treatment for these diseases today. 1 Marrow transplant also shows potential promise as a treatment for some hemoglobinopathies. 2

Good nutritional status of patients undergoing bone marrow transplants is crucial to promote optimum conditions for the survival of the patient. Bone marrow recipients are severely immunocompromised from total body irradiation, chemotherapy, and from the basic disease processes. Post transplant severe infections occur commonly. The prescribed diets for these patients include parenteral hyperalimentation, sterile food service, reduced bacteria foods, or modified house diets.

1 Patricia Stream, "Functions of the outpatient Clinic Before and After Marrow Transplantation", Nursing clinics of North America, Vo1. 18, No.3, September, 1983, pp.603.

2 F.L. Johnson, A.T. Look, et. a1., "Marrow Transplantation for Sickle Ce11 Anemia". Abstract from the $25 \mathrm{th}$ Annual Meeting of the American Society of Hematology. Blood, Vo1.62, No. 5, Supplement 1 , November, 1983, pp. 223a. 
Bone marrow transplantation is such an expensive procedure that every measure is taken to ensure success. Good nutritional status is important to this success as it will provide substrates for cellular growth and repair. Hospitalization time is approximately two to three months which is expensive in terms of food and nutrition services. The goal is to determine the best way to feed these patients when many are unable to consume adequate amounts of food to support their individual nutrient needs. Ultimately, information provided with this study may pave the way for adjusting reimbursement fees. To date, no published data has been found on development of a food service system for bone marrow transplantation or on comparative studies of the food and nutrition services at the existing BMT centers in the United States.

This study was designed to survey current food and nutrition services in BMT centers in the United States. The purpose of the research was to answer the following questions:

1. What were the similarities in the organization and size of foodservice at BMT centers?

2. What were the similarities in the organization and size of medical nutrition services provided at BMT centers?

3. Was there an expressed need by the registered dietitian working in these units to standardize these services for cost-effectiveness and efficiency?

4. Can a model be established from existing BMT centers to build/implement food and nutrition servics for a new center? 


\section{CHAPTER II}

\section{REVIEW OF LITERATURE}

I. History of Bone Marrow Transplantation

Tissue transplantation is the transfer of living matter or cells from one individual to another, with the "objective of maintaining the functional integrity of the transplanted tissue in the recipient". 1 Transplants are categorized by the genetic relationship between donor and recipient and by the site of transplantation. An allograft is a transplant between members of the same species.

Allografts may be rejected through either cell mediated or a humoral immune reaction of the recipient against antigenic components that are present on the donor's cell membranes. The strongest antigens are governed by a complex of genetic loci termed Human Lymphocyte Antigens, ("HLA"). Together with the major blood group ( $A B O$ ) antigens, they constitute the most important transplantation antigens in man. Since transplantation antigens can be identified by their effect in vitro, tissue typing is possible.2

Prior to transplantation, histocompatibility typing of peripheral blood and bone marrow cells of the donor and recipient is always performed. The goal is to identify the HLA antigens serologically and, by appropriate donor selection,

1 The Merck Manual, 13 th ed. Berkow and Talbot, Editors. Merck and Co., Inc. Rahway, N.J., 1977, p. 243.

2 Ibid., p. 244 . 
minimize the antigenic differences between donor and recipient. The most compatible donors are an identical twin, paternal twins, siblings, or parents, in that order.

Marrow transplantation techniques have progressed in the past 20 years from an experimental procedure to an effective treatment of leukemias and other related blood disorders. 1 There is agreement that marrow transplantation following high dose chemotherapy and/or total body irradiation is a successful therapy for some patients with leukemia and severe aplastic anemia. 2,3 Bone marrow transplantation produces a median remission equal to or longer than any reported results from current chemotherapy protocols in patients with acute leukemia who have relapsed. It offers the possibility of long remissions for $15-30 \%$ of these patients.4

1 M. Hutchison, K. Itoh, "Nursing Care of the Patient Undergoing Bone Marrow Transplantation for Acute Leukemia", Nursing Clinics of North America, Vol. 19, No. 4, December, 1982, p. 697.

2 E.D. Thomas, "The Use and Potential of Bone Marrow Allograft and Whole-body Irradiation in the Treatment of Leukemia", Cancer, 50:1449-1454, 1982 .

3 R. Storb, E.D. Thomas, L.D. Buckner, et al. "Marrow Transplantation in Thirty 'Untransfused' Patients with Severe Aplastic Anemia", Annals of Internal Medicine, 92:30-36, 1980.

4 E.D. Thomas, "The Role of Marrow Transplantation in the Eradication of Malignant Disease", Cancer, 49:1963-9, 1982. 
The acute leukemias are defined as "rapidly fatal forms of leukemia" (generalized neoplastic disorders of the blood-forming tissues, primarily those of the leukocytic series). They are characterized by replacement of normal bone marrow cells by immature or blast cells (precursors to leukemic cells) of the blood-forming series. 1

About one-half of patients with acute nonlymphocytic leukemia (ANLL) survive more than three months after bone marrow transplant and one-fifth survive over the first year. 2

Children with acute lymphocytic leukemia (ALL) on standard risk protocols, the most common type in childhood, are initially treated with current chemotherapy regimens that offer projected cure rates of up to $80 \%$. In those children who relapse after a second or later course of chemotherapy, bone marrow transplantation from a HLA compatible sibling can yield a $5 \%$ to $30 \%$ long-term survivial. In the less common acute nonlymphoblastic leukemias of children, where chemotherapy is less successful, bone marrow transplant may be used after the first relapse. 3 In one series of children so treated, there was better than $50 \%$ survival for more than five years. 4

1 The Merck Manual, pp. 327-328.

2 Patricia Walker, "Bone Marrow Transplant; A Second", Nursing, January, 1977 , pp. 25-26.

3 Diagnostic and Therapeutic Technology Assessment (DATTA), American Medical Association. Journal of the American Medical Association, Vo1. 251, No. 16, Apri1 27, 1984, ppp.2155.

4 F.L. Johnson, E.D. Thomas, B.S. Clark, et. al. "A Comparison of Marrow Transplantation with Chemotherapy for Children with Acute Lymphoblastic Leukemia in Second or Subsequent Remission". New England Jounal of Medicine, Vol. $305,1981, \mathrm{pp} .846-851$. 
The transplantation procedure consists of an aspiration of marrow from a compatible donor and subsequent intravenous infusion into the recipient after the recipient's marrow has been irradiated. 1 The objective of marrow transplantation is to destroy the leukemic cell population in the patient first by high dose chemotherapy and/or radiation, then to replace these cells with normal cells from a donor's marrow. Chemotherapy and radiation treatments suppress the patient's immune system so the healthy marrow cells from the donor will be accepted. After irradiation, the patient receives marrow from the donor intravenously infused, usually over a four hour period. A central venous catheter is inserted before transplantation (usually a single or double right atrial catheter). 2 All total parenteral nutrition, blood products, and parenteral drugs may be infused through this catheter.

1 The Merck Manual, pp. 339.

2 S.N. Aker, J.E. Cheney, et. al. "Nutritional Support in Marrow Graft Recipients with Single versus Double Lumen Right Atrial Catheters". Experimental Hematology, Vo1. 10, No.9, october, 1982 , pp. $7 \overline{32}$. 


\section{Post-Transplant Complications}

Transplanted patients maintain pronounced immunologic impairment for up to four months following this procedure. It takes usually 12 to 18 months before most patients regain normal immune reactivity. Pneumonia is present in approximately $40 \%$ of all patients surviving 30 days after transplant. 1

After transplantation, there is a period of 10-20 days before the donor stem cells in the marrow cavities proliferate and mature. 2 During this waiting period the patient will become granulocytopenic. There is an absence of circulating granulocytic leukocytes caused by suppression of marrow from chemotherapy and radiation. Granulocytopenia is of critical concern because it predisposes the marrow transplant patient to life-threatening infections, ${ }^{3}$ as later described.

1 R.P. Witherspoon, R. Storb, H.D. Ochs, et. al.: "Recovery of antibody production in human allogenic marrow graft recipients: influence of time post transplantation, the presence or absence of chronic graft-versus-host-disease and antithymocyte globulin treatment". Blood, Vol. 58, 1981, pp. 360-368.

2 K.J. Isselbacher, R.D. Adams, E. Braunwald, et. al. (eds): Harrison's Principles of Incernal Medicine. E. D. Thomas "Bone Marrow Transplantation: Present Strategy and Future Expectations" 9th edition: Update 1 McGraw-Hi11, N.Y., 1982.

3 L. Fox, "Granulocytopenia in the Adult Cancer Patient", Cancer Nursing, Vol. 4, pp.459-465, 1981 . 
Graft versus Host Disease (GVHD) is a major impediment to the success of marrow transplants, occurring in the acute form in approximately $45 \%$ of all patients. It is a syndrome in which new circulating competent donor T-lymphocytes immunologically attack the host tissue. Treatment for GVHD is still being improved, for there is no satisfactory cure for this condition. High doses of steroids, methotrexate, antithymocyte globulin and cyclosporin have been used effectively in some cases. 1

GHVD is clinically manifested in the skin, liver and gut. The symptoms of gastrointestinal GVHD include nausea, vomiting, anorexia, abdominal cramping, secretory diarrhea and altered $\operatorname{motility.2}$

1 Hutchison, et. a1., p. 706.

$2 M \cdot M$. Hutchison, K. Itoh, "Nursing Care of the Patient Undergoing Bone Marrow Transplantation for Acute Leukemia", Nursing Clinics of North America, Vol. 17, No. 4, December, 
With the increase in numbers of long-term survivors, chronic GVHD has also become a significant complication of allogenic marrow transplantation. The reported incidence is $25-50 \%$ of a 11 long-term survivors. Chronic GVHD of the gastrointestinal tract is characterized by esophogeal symptoms of dysphagia, heartburn, regurgitation and weight 1oss. oral symptoms include xerostomia, dysgeusia, cheilosis, tooth decay and burning after the ingestion of acidic foods. 1 These symptoms have persisted in some patients 2 to 5 years post transplant. other gastrointestinal complications are steatorrhea due to the lack of intestinal bile salts, and malabsorption. 2

Herpes simplex, herpes zoster, pneumococcus, staphylococcus or streptococcus infections may occur after 100 days post transplant. Viral infections are also commonly observed after BMT. One study isolated adenovirus from 51 out of 1051 patients undergoing marrow transplants between 1976 and 1982.3 Relapse of leukemia may occur at any time after transplantation.

1 P. Stream, "Functions of the Outpatient Clinic". Symposium on Bone Marrow Transplantation, September, 1983.

2 S.N. Aker, et. al. "Nutritional Considerations", pp. 593. 3 A.F. Shields, et. al.: "Adenovirus Infections in patients Undergoing BMT'. NEJM, Vol. 312, No. 9, February, 1985, pp. 529-533. 
Hepatic veno-occlusive disease has been recognized as a complication of the chemo-radiation therapy pre-transplant, and develops in 1 to 3 weeks post transplant. Symptoms include sudden weight gain, hepatomegaly, ascites, jaundice and encephalopathy. 1 It occurs in $20 \%$ of the patients and can be fata 1.2

1 S.N. Aker, pp. 592.

2 H.M. Shulman, B.B. McDonald, D. Matthews, et. al. "An Analysis of Hepatic Venocclusive Disease and Centrilobular Hepatic Degeneration following Bone Marrow Transplantation". Gastroenterology, Vol. 79, 1980, pp. 1178-1191. 
IV. Nutritional Considerations of Bone Marrow Recipients

The adverse effects of nutritional deprivation on transplanted hematopoietic cells in mice have been studied. It was reported that "nutritional deprivation during the period immediately following bone marrow transplantation can have detrimental effects on the growth of the marrow graft". Stuart and Sensenbrenner suggested that nutritional support of patients with reversible bone marrow suppression is warranted, since poor nutrition can delay the return of normal hematopoietic function.l

Table 1 summarizes nutritional complications of bone marrow transplantation:

1 R.K. Stuart, L.L. Sensenbrenner, "Adverse Effects of Nutritional Deprivation on Transplanted Hematopoietic Cells". Experimental Hematology, Vol. 7, No. 8, September, 1979, pp. 441 . 
Nutritional Complications of Bone Marrow Transplantation

Nausea/ Malab-

Anorexia Stomatitis Esophagitis Vomiting Diarrhea sorption Ileus

a r iy ing

iease

reductive

zmotherapy

11 body

:adiation

non-

orbable

ibiotics

ctions

emic

ibiotics

no-

pressive

gs

monitis

$+$

$+\quad+$

$+$

$+$

$+$

$+$
$+$

$+$

$+$

$+$

$+$

$+$

$+$

$+$

$+$

$+\quad+$

$+$

$+$

$+$

$+$

$+\quad+$

$+\quad+$

$+$

$+$

$+\quad+$

SOURCE: R.K. Stuart, L.L. Sensenbrenner, "Adverse Effects of Nutritional Deprivation on Transplanted Hematopoietic Cells". Experimental Hematology Vo1. 7, No. 8, 1979, pp. 436. 
Gastrointestinal problems result from radiation, chemotherapy, medications and infection. The total body irradiation may cause nausea, vomiting and diarrhea lasting 24 to 48 hours in acute cases. Inflammation of the mucous membrane or epithelium may occur in varying levels of severity. Xerostomia (dry mouth) develops after radiation treatment and may persist for years after the transplant. 1 Dysgeusia (temporary loss or perception changes of taste) complicates the anorexia frequently observed and continues until approximately $30-50$ days post transplant.2

Table 2 depicts some common medications that alter nutritional status of the patient:

1 B.A. Cunningham, et. a1., pp. 591.

2 Ibid., pp. 592 . 
Table 2

Medications that Impact Nutritional Status

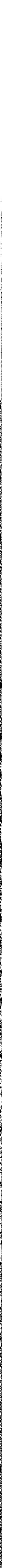

SOURCE: S.N. Aker, P. Lenssen, et. al., "Nutritional Assessment in the Marrow Transplant Patient". Nutritional Support Services, Vol. 3, No. 10, october, 1983, pp. 24. 
A major nutritional goal for rehabilitation in these patients is to prevent negative nitrogen balance and loss of lean body mass without overloading the patient with excess energy and fluid. 1 At the Fred Hutchinson Cancer Research Center, patients who are able to take in orally at least one-half the minimum energy and protein requirements and maintain weight, are taken off parenteral nutrition. This takes approximately 25-45 days in some patients.2 When there is a rise in the granulocyte count (usually to $500 / \mathrm{mm}^{3}$ ), and the patient is able to tolerate foods orally (ideally at least $1000 \mathrm{kilocalories/}$ day), he is usually discharged from the hospital. Patients are sometimes discharged on hyperalimentation when they are unable to consume adequate energy orally. The patient usually returns to the transplant unit on a yearly basis for follow-up examinations. 3

1 B.A. Cunningham, P. Lenssen, S.N. Aker, et. a1., "Nutritional Considerations During Marrow Transplantation", Nursing Clinics of North America, Vol. 18, No. 3, Septemer, 1983, pp. 591.

2 P. Lenssen, et. a1., "Parenteral Nutrition in BMT Recipients After Discharge from the Hospital". Experimental Hematology, Vo1. 11, No. 10, November, 1983, pp. 975.

3 Patricia stream, pp. 603-609. 
V. Food service to the BMT Recipient

Types of food used and manner of service can contribute significantly to the introduction of potential pathogens. These acquired organisms can be virulent and are likely to be resistent to systemic antibiotics. 1 There have been numerous reports describing the general incidence of food contamination from hospital kitchens and the risk for patient-acquired infections. 2 This potential food contamination is of special concern to the severely immuno-compromised bone marrow recipient as addressed earlier.

According to Aker, 3 three types of diets have been identified as suitable for the BMT patient:

1. Sterile food service - It uses foods that have no bacterial or fungal growth and is defined as a "no-risk" food. If a food is not canned, then sterility can be accomplished by autoclaving, irradiation or oven-baking. Bacteriologic monitoring is required for every batch of food processed. To date, the Fred Hutchinson Cancer Research Center is the only center in the U.S. approved by the D.F.A. to irradiate foods for human consumption in ultraisolation environments. This type of foodservice requires the use of separate kitchen facilities and is labor-intensive.

1 S.N. Aker, C.L. Cheney, "The Use of Sterile and Low Microbial Diets in Ultraisolation Environments". Journal of Enteral and Parenteral Nutrition. Vol. 7, No. 4, July/August, 1983, pp. 390.

2 Ibid, pp. 390

3 Telephone interview with Saundra N. Aker, R.D., Director of the Clinical Nutrition Unit at the Fred Hutchinson Cancer Research Center, Seattle, Washington, November 1, 1984. 
The following cartoon and caption (Figure 1), summarizes what is involved in the preparation of one food item in a sterile foodservice:

Figure 1:

SOURCE: S.N. Aker, "On the Cutting Edge of Dietetic Science". Nutrition Today, Vol. 19, No. 4, July/August, 1984, pp. 25. 
2. Cooked food diet - This includes foods that have a minimum number of colony-forming units allowed. Guidelines for this type of diet are described by Pizzo, Purvis and Waters. 1 Foods they considered safe for patient consumption were those in which microbiological cultures yielded less than 500 Bacillus species per gram or cubic centimeter. The growth of most other organisms (regardless of colony count) generally resulted in rejection of the tested product. This type of food service also requires a separate kitchen and an autoclave.

3. Low microbial diet - Includes well-cooked foods and the elimination of potentially pathogen-containing foods. "The goal is to reduce the total bacterial content of foods and eliminate bacteria and fungi that have high pathogenicity".2 Food service usually comes from a main hospital kitchen using some special handling techniques. There is an unknown quantity of organisms in these foods although institutions frequently culture a variety of foods when initiating the service to establish acceptable foods.

1 P.A. Pizzo, D.S. Purvis, D. Waters, "Microbiological Evaluation of Food Items". Journal of the American Dietetic Association, Vol. 81 , September, 1982 .

2 Aker, Cheney, pp. 391. 
There have been contradictory reports on the immunological benefits of patients receiving sterile versus cooked food diets in protective environments as indicated by Aker and Cheney. These authors conclude that "there has been a lack of adequate description of specific foods and preparation methods of these special diets, such that duplication of the studies and valid comparisons cannot be confident1y made". 1

VI. Cost/Diagnosis-Related Groups Implications

The cost of a bone marrow transplant procedure has been cited as ranging from $\$ 60,000.00$ to $\$ 150,000.00 .2$ Aker, 3 reported an average cost of $\$ 750.00 /$ day excluding antibiotics, TPN, etc. The Diagnosis Related Groups (DRG's) is a perpective payment system for healthcare to promote cost containment. This type of cost containment places a price, based on the diagnosis, on each case treated. The per case payment is predetermined and fixed, allowing the hospital to retain any revenue over costs but placing it at risk if costs exceed revenue. 4 The reimbursement of this DRG (非 3445.41 or $\$ 41.0$, or $\$ 405.0$ ), depending on the

1 Aker, Cheney, pp. 392-394

2 B. Conrad, "Replacing the Body's Parts", Newsweek, August $29,1983, \mathrm{pp} .40$.

3 Telephone interview with Sandra Aker, R.D. 4 Physician's Guide to DRG's. American Medical International, 
primary diagnosis, relative weight, location and type of institution in which it is performed ranges from approximately $\$ 2,000.00$ to $\$ 5,000.00$. This DRG price is far below the actual cost of the procedure. At Boston Children's Hospital, bone marrow transplant patients are "in for months at a time" because the procedure is "very prone to complications". 1 The average length of stay is reported to be 45 days.

Currently, children's hospitals are exempted from Medicare's prospective payment system and from most similar state payment programs. 2 However, the exemption is considered temporary. 3 Community hospitals with pediatric services in the past tried to "hold on to" the patients because insurance companies reimbursed the total bil1. With increasing competition and DRG's, they now tend to refer the pediatric patient to children's hospitals, particularly if they're in a position of being underfunded from third party payors. The National Association of Children's Hospitals and Related Institutions (NACHRI) is currently undergoing a study to enable consideration of a severity of illness case mix system to the upcoming DRG implementation in

1 L. Punch, "DRG's + Complex Caseload = Trouble for Children"s Hospitals". Modern Healthcare, October, 1984 , pp. 64.

2 L. Punch, pp. 62 .

3 ADA Courier, "Work Begins on DRG's for Pediatric Care". September/october, 1984 , pp. 8 . 
children's hospitals.1 The U. S. Department of Health and Human Services, Division of Maternal and Child Health recently sponsored a meeting of various medical disciplines to recommend that the NACHRI update its 1978 "uniqueness study" to include clinical nutrition among services that are (or should be) available in children's hospitals. 2

1 NACHRI, The Children's Hospitals' Case Mix Classification System.

2 ADA Courier, pp. 8 . 
METHODS

Descriptive research systematically describes the facts and characteristics of a given population both accurately and factually. Questionnaires are constructed to collect the following types of data:

1. Factual information that described existing phenomena.

2. Identification of problems and justification of current practices.

3. Comparison and evaluation.

4. Determination of what others were doing to benefit from their experiences in making future plans and decisions.

The use of a mailed questionnaire is primarily for cost containment. 1 other advantages and disadvantages include the following: 2,3 Advantages:

1. Time saving.

2. The questionnaire may be completed at the respondent's convenience.

3. Greater assurance of anonymity.

4. Standardized wording.

5. No interviewer bias.

6. Securing information from records, colleagues, etc. is possible.

7. Accessibility of respondents.

1 Stephen Isaac, William B. Michael, Handbook in Research Evaluation, 2nd ed., San Diego, CA:EDITS, 1982, pp.46.

2 Kenneth D. Bailey, Methods of Social Research, 2nd ed., New York: The Free Press, 1982, pp. 156-159.

3 Mark L. Berenson, David M. Levine, Basic Business Statistics, 2nd ed., New Jersey: Prentice-Hall, 1983, pp. 12. 
Disadvantages: 1,2

1. Lack of flexibility.

2. Low response rate.

3. Written behavior only.

4. No control over environment.

5. No control over question order.

6. Questions may go unanswered.

7. No control over date of response.

1 Kenneth d. Bailey, Methods of Social Research, 2nd ed., New York: The Free Press, 1982, pp. 156-159.

2 Mark L. Berenson, David M. Levine, Basic Business

Statistics, 2nd ed., New Jersey: Prentice-Hall, 1983, pp. 12. 
CHAPTER III

METHODS

I. Introduction - This study was designed to gather information from existing food and nutrition services in bone marrow transplant centers which might serve as a basis for developing a model protocol for such units. The data collection instrument was a questionnaire and cover letter. Responses were analyzed for similarities and differences between individual centers. II. Instrument - A questionnaire was constructed to gather information on current protocols and procedures of food and nutrition services in all bone marrow transplant centers in the United States. This instrument was evaluated by faculty and graduate students enrolled in Research Methods, at Florida International University, Miami, Florida. The revised questionnaire and coverletter were reviewed by Sandra Aker, R.D., Director of the Clinical Nutrition Unit at the Fred Hutchinson Cancer Research Center, Seattle, Washington. She has published numerous articles on food and nutrition services for BMT patients based on experience at her center. She agreed to review and comment on the instrument before the final form was distributed. Comments were reviewed and implemented. The questionnaire and coverletter (Appendix 1) were mailed on February 5, 1985. A stamped, return envelope was included and anonymity was assured. 
Respondents were given the opportunity to obtain a summary of the results if so requested, otherwise, there was no identification of respondents. The items on the questionnaire were grouped into three categories:

1. Background information on the characteristics of the center for coding purposes.

2. Nature of foodservice, delivery systems and individual food characteristics.

3. Length and breadth of medical nutrition services provided.

III. Population - The questionnaire was sent to all chief dietitians associated with existing bone marrow centers in the United States from a list of centers prepared by the International Bone Marrow Registry, June $16,1982$. IV. Statistical Analysis - Returned questionnaires were hand-scored. Data were grouped according to number of beds in each unit. Telephone interviews were held if necessary to clarify responses. The responses to categorical questions were tallied as percentages and as frequency distributions. The mean and median were computed for the quantitative questions.

The following variables were compared to determine the presence of similarities in the organization and size of the food service among centers:

a. Type of room and number of beds.

b. Type of room and type of diets. 
c. Number of beds and type of diets.

d. Year that transplants were first performed and type of diets.

e. Problems encountered when food service was developed.

f. Type of food service and existence of a research kitchen.

g. Type of diet and staffing.

h. Well-accepted food items.

1. Average patient length of stay and type of food service.

j. Type of food service and hours of tray delivery and weighing of foods.

The variables compared to determine similarities in the organization and size of medical nutrition services provided among centers are listed below:

a. Number of beds and existence of separate full time equivalent (FTE) dietitians and scheduling.

b. Type of food service and extent of dietitian coverage. c. Incidence of dietitian services in various treatment categories.

d. Existence of fee for service. 
CHAPTER IV

\section{RESULTS AND DISCUSSION}

The results described below reflect respondents' answers to the items on the questionnaire. They are described here in order of grouping on the questionnaire: background information, food service and medical nutrition services.

of the 35 questionnaires mailed, 30 (86\%) were returned. Eight centeres reported that they no longer had functioning bone marrow transplant units. Two centers reported that there was a lack of funding. One center reported a temporary closure, one was transferred to another hospital and one center reported that the unit was closed because the first few patients treated had died. Three centers answered that they no longer had a unit but did not give a reason. Two centers reported never having a BMT unit although they were 1 isted on the International Bone Marrow Registry, 1982. The total number of responding centers with functioning BMT units were twenty.

Thirteen of the 20 existing units were associated with both a hospital and a university. Fourteen units operated at capacity or one or two below capacity. In two centers with 18 beds each, they reported an average census of $44 \%$ and $77 \%$ occupancy, respectively.

A11 but one center reported admitting leukemias and aplastic anemias. Thirteen centers reported treating severe immunodeficiency disease syndromes as well. Four centers listed neuroblastomas. The following diseases were also listed, each by one 
center only: Hodgkin's disease, melanoma, breast and solid tumors, thallasemia, lymphoma, mucopolysaccharidosis and osteopetrosis. The range of patient stay was 14-90 days, with an average of $34-74$ days. The reported years when BMT's were first performed were equally distributed from 1975-1980 and 1981-1983, with the peak numbers in 1976 and 1981 .

The similarities in the organization and size of the food service at BMT centers were examined. The first item compared was the year that BMT's were first performed and type of food service employed (table 3$)$. 
Table 3

COMPARISON OF DATES THAT BMT'S WERE

FIRST PERFORMED AND TYPE OF FOOD SERVICE

\begin{tabular}{lcccc}
\hline YEAR & SF* & MBt & MH" & COMBO\# \\
\hline $1969-74$ & -- & - & -- & 1 \\
$1975-80$ & 1 & 4 & 3 & - \\
$1981-83$ & -- & 4 & 2 & 2 \\
\hline
\end{tabular}

*SF $=$ sterile food service.

$+M B=$ modified bacteria means either a low or reduced bacteria diet.

$" M H=$ modified house means a house diet without fresh vegetables and/or fruits.

\# $\mathrm{COMBO}=$ usage of any two above diets in one center. 
opening dates of BMT units were categorized into three groups: 1969-1974, 1975-1980, and 1981-1983. In the 1969-1974 group, there was one center that started performing BMT's. It employed a combination of diets (both sterile diet and modified house diet). In the 1975-1980 group, eight centers started transplantations. One center reported using a sterile food service, four used a modified bacteria diet (either a low or reduced bacteria diet), and three used a modified house diet (house diet without fresh vegetables and/or fruits). In the 1981-1983 category, two of eight used a combination diet, four 1isted a modified bacteria diet and two used a modified house diet. The first center that started BMT's (1969) used both a sterile food service and a modified diet. Four of eight centers between 1975-1980 also used modified bacteria diets. It is indicated from these data that the newer centers tended to use the more liberal diets; either modified bacteria or modified house diets.

Also of interest were problems listed as arising during development of the food and nutrition services. These are included in table 4. 
Table 4

PROBLEMS DURING DEVELOPMENT OF FOOD SERVICE

Problem

Sterile food

(cost/lack of guidelines/tests)

Availability of single-serve items

Lack of appropriate facilities

Educating kitchen personnel on sterile technique

Anticipating patient requests
Number of Centers

9

2

2

1

1 
The most frequently reported problems were associated with the development of a sterile food service system. In addition, the availability of single-serve items can also be associated with sterile food service. The problems inherent with sterile food service appeared to be a major deterrent for the centers surveyed.

Four centers reported changing from a sterile food service to either a modified bacteria or modified house diet at one point in their operation. Reason for these changes are given in table 5.

Table 5

REASONS FOR CHANGING FROM STERILE FOOD SERVICE

$\underline{\operatorname{Reason}}$ Number of Centers

Patient acceptance of taste. 2

Diet changed by request of 1 administrative head.

Kitchen was too far from the unit

for practical delivery. 
Evidence of similarities in types of rooms used when compared to the size of the unit was a1so examined. Table 6 lists the type of rooms used according to number of beds in the unit:

Tab1e 6

Comparison of Number of Beds and Type of Rooms in BMT Units

\begin{tabular}{|c|c|c|c|c|c|c|c|c|}
\hline$\#$ & BEDS & \# IN & CATEGORY & LAE / HEPA* & LAF \& & ISOLATION & ISOLATION & ONLY \\
\hline & -5 & & 6 & 3 & & 1 & 2 & \\
\hline 6 & -10 & & 5 & - & & 3 & 2 & \\
\hline & er 10 & & 6 & 2 & & 1 & 3 & \\
\hline
\end{tabular}

* LAF/HEPA - Laminar Air Flow (LAF) or High Efficiency Particulate Air Filter Units. Both are highly controlled air environments. 
The number of beds were categorized as follows: one to five beds, six to 10 beds, and over ten beds. Surveys indicated that there were six centers in the one to five bed category. Three of these six centers used Laminar Air Flow (LAF) /High Efficiency particulate Air Filter (HEPA) rooms, one used both laminar air flow and isolation rooms and two centers used isolation rooms only. In the six to ten bed category, three of five used both laminar air flow and isolation rooms and two used isolation rooms only. There were six centers in the over ten bed category. Two used LAF/HEPA rooms, one used both laminar air flow and isolation rooms, three used isolation rooms only. None of the centers in the six to ten bed category used laminar air flow rooms only. The rest showed no pattern between the number of beds and type of rooms. Existence of a pattern between type of room used and type of diet was then analyzed. Table 7 illustrates the comparison between type of room and type of diet: 


\section{Table 7}

Comparison of Room Types and

Diet Types in BMT Units

\section{DIET TYPE}

\begin{tabular}{|c|c|c|c|c|c|c|}
\hline ROOM TYPE & IN & CATEGORY & $\mathrm{SF} *$ & $\mathrm{MB}+$ & MH" & COMBO \# \\
\hline $\mathrm{LAF} / \mathrm{HEPA}$ ข & & 5 & 1 & 2 & 1 & 1 \\
\hline LAF \& Isolation & & 7 & - & 4 & - & 3 \\
\hline Isolation on $1 \mathrm{y}$ & & 7 & - & 2 & 5 & - \\
\hline
\end{tabular}

* $S F=$ sterile food service.

$+M B=$ modified bacteria means either a low or reduced bacteria diet.

" $\mathrm{MH}=$ modified house means a house diet without fresh vegetables and/or fruits.

\# СОмВо = usage of any two diets in one center.

I LAF/HEPA = Laminar Air Flow (LAF) or High Efficiency Particulate Air Filter units. Both are highly controlled air environments. 
Among the five units using laminar air flow (LAF) or High Efficiency Particulate Air (HEPA) rooms, one used a sterile food service, one used a combination diet, two used a modified bacteria diet, and one used a modified house diet. Among the seven centers using both LAF rooms and isolation rooms, one used a sterile diet, two used a combination diet and four used a modified bacteria diet. of the seven centers that used isolation rooms only, two used a modified bacteria diet and five used a modified house diet. The modified house diet was most frequently reported (five of seven) with isolation rooms. The modified bacteria diet was most frequently reported (four of seven) with combination diets. None of the centers with isolation rooms only used a sterile diet. They used either a modified bacteria or modified house diet. One of the 20 centers used a sterile food service only. These data suggest a trend away from strictly sterile diets to more liberal forms of food service.

The number of beds in the unit and type of diet were also compared (table 8): 
Table 8

Comparison of Number of Beds and

Diet Types in BMT Units

\section{DIET TYPE}

\begin{tabular}{|c|c|c|c|c|c|c|}
\hline$\#$ BEDS & \# IN & CATEGORY & $\mathrm{SF}^{*}$ & MB+ & MH " & Сомво\# \\
\hline $1-5$ & & 5 & - & 3 & 2 & - \\
\hline $6-10$ & & 7 & 1 & 3 & 2 & 1 \\
\hline over 10 & & 6 & - & - & 3 & 3 \\
\hline
\end{tabular}

* SF = sterile food service

$+M B=$ modified bacteria means either a low or reduced bacteria diet.

" $M H$ - modified house means a house diet without fresh vegetables and/or fruits.

\# COMBO = Usage of any two above diets in one center. 
In the one to five bed category, three used modified bacteria diets and two used a modified house diet. In the six to ten bed category, one reported a sterile diet, one used a combination diet, three reported a modified bacteria diet and two centers listed a modified house diet. In centers with over ten beds, three used a combination diet and three indicated a modified house diet. There was no pattern between number of beds in the unit and type of diet served. The modified bacteria diet was most frequently reported for those units in the categories of one to five and six to ten beds (six of twelve). Comparison of type of diet to both number and type of beds in the unit indicated that the modified bacteria or modified house diet was most frequently employed.

The relationship between the type of food service, existence of a research (separate) kitchen and staffing is described in table 9. 
Table 9

Comparison of Diet Type, Existence of a

Research Kitchen and Staffing in BMT Units

\begin{tabular}{|c|c|c|c|c|c|c|c|c|c|}
\hline DIET TYPE & 非 & $I N$ & CATEGORY & SEPARATE & KITCHEN & \# & COOKS & 非 & SHIETS \\
\hline$S F^{*}$ & & & 1 & 1 & & & 2 & & 2 \\
\hline $\mathrm{MB}+$ & & & 8 & 2 & & & 1 & & 2 \\
\hline $\mathrm{MH} "$ & & & 8 & 2 & & & $3-4$ & & 1 \\
\hline COMBO\# & & & 3 & 2 & & & 1,2 & & 1,3 \\
\hline
\end{tabular}

* $\mathrm{SE}=$ sterile food service.

$+M B=$ modified bacteria means either a low or reduced bacteria diet.

$" \mathrm{MH}=$ modified house means a house diet without fresh vegetables and/or fruits.

\# 
The center using sterile food service listed a separate kitchen with two cooks working two shifts. Of the three centers with combination diets, two had separate kitchens with either one cook and one shift or two cooks with three shifts. of the eight centers employing a modified bacteria diet, two had a separate research kitchen with one cook working two shifts. Two of the eight centers using a modified house diet had a separate kitchen. One reported $3-4$ cooks in one shift, the other did not report. Both units using combination diets had a research kitchen as did the center which served a sterile food diet. Six of the eight units using modified house diets and six of the eight centers using modified bacteria diets did not have separate kitchen facilities for BMT patients.

of the seven centers with research kitchens, there was from one to four cooks per shift and one to three shifts per day.

A11 centers reported that training the cooks was performed at the hospital itself. Incidence of inservice training varied among the centers. Five of the 20 units reported conducting audits to document standardized techniques and four listed existence of bacteriological monitoring of foods (two were sterile diets and two were modified bacterial diets).

Foods that were 1 isted as particularly well-accepted by the patients are listed in table 10 . 
Table 10

Foods Particularly Well-accepted by the BMT Patients

\begin{tabular}{|c|c|c|c|c|c|c|}
\hline FOOD PREPARAT & MILK & MEAT & FRUIT & BREAD & BEVERAGE & MISC. \\
\hline AUTOCLAVED & & $\begin{array}{l}\text { Poultry } \\
\text { Stouffer's } \\
\text { Green Giant } \\
\text { Boil-in bag foods }\end{array}$ & & Hot cereals & Koolaid & Popcorn \\
\hline WELL-COOKED & & $\begin{array}{l}\text { Hot dog } \\
\text { Grilled cheese sandh } \\
\text { Fried chicken } \\
\text { Bacon, sausage } \\
\text { Hard-cooked (eggs) }\end{array}$ & ich & $\begin{array}{l}\text { Oven baked tarts } \\
\text { Potatoes } \\
\text { Noodle soup } \\
\text { Pizza } \\
\text { Corn on cob }\end{array}$ & & Popsicle \\
\hline $\begin{array}{l}\text { PREPACKAGED/ } \\
\text { CANNED }\end{array}$ & $\begin{array}{l}\text { Borden's } \\
\text { Frosteds } \\
\text { Sustacal } \\
\text { Pudding }\end{array}$ & $\begin{array}{l}\text { Canned Chinese food } \\
\text { P. Butter \& crax } \\
\text { Cheese \& crax } \\
\text { Kraft mac \& cheese }\end{array}$ & Applesauce & $\begin{array}{l}\text { Pepperidge Farm } \\
\text { Individual cookies } \\
\text { Baked beans } \\
\text { Soups } \\
\text { Twinkies } \\
\text { Cupcakes } \\
\text { Spaghettios } \\
\text { Lorna Doone } \\
\text { Sugared cereals }\end{array}$ & $\begin{array}{l}\text { Fruit juice } \\
\text { Hawain punch } \\
\text { Hot choc. }\end{array}$ & $\begin{array}{l}\text { Lifesavers } \\
\text { Popsicle in } \\
\text { tube }\end{array}$ \\
\hline
\end{tabular}


One center reported that patients particularly did not like Real Fresh milk (sterile milk) or sterilizied ice. The food groups most frequently listed in all diet types were meats, breads, and beverages. No center listed red meats or vegetables, however, they may have been included in the boilin-a-bag foods. Foods listed in this survey were generally in agreement with other reports of patients' likes and dislikes who were experiencing a change of taste perception, numbess and higher threshold for sweet foods and a lower threshold for bitter foods. 1

other parameters examined for similarities were type of food service, hours of food delivery and existence of food weighing (table 11). Several centers did not respond to this portion of the questionnaire. Consequently, the totals for the results do not equal twenty.

1 B.A. Cunninghan, P. Lenssen, S.N. Aker, pp. 591-592. 
Table 11

Comparison of Diet Type, Hours of Food

Delivery and Existence of Food Weighing

\begin{tabular}{|c|c|c|c|c|c|}
\hline DIET TYPE & $\#$ IN & CATAGORY & $\begin{array}{c}\text { HOURS OF FOOD } \\
3 \text { MEALS/SNACKS }\end{array}$ & $\frac{\text { DEL IVERY }}{\text { CONTINUOUS }}$ & $\begin{array}{c}\text { FOOD ROUTINELY } \\
\text { WEIGHED }\end{array}$ \\
\hline$S F^{*}$ & & 1 & 1 & - & - \\
\hline $\mathrm{MB}+$ & & $6{ }^{\prime}$ & 2 & 3 & - \\
\hline $\mathrm{MH}^{*}$ & & 7 & 5 & 2 & 1 \\
\hline COMBO非 & & 31 & - & 2 & 1 \\
\hline
\end{tabular}

- one center did not report

* $S F=$ sterile food service.

$+M B=$ modified bacteria means either a low or reduced bacteria diet.

" $\mathrm{MH}=$ modified house means a house diet without fresh vegetables and/or fruits.

\# COMBO = usage of any two of the above diets in one center. 
The center with sterile food service served three meals and snacks daily. Food was not routinely weighed. The two centers using a combination diet used a continuous feeding (on demand) schedule. Food was routinely weighed in one of the two centers. Five centers offering modified bacteria diets reported. Two used meals and snacks and three used continuous feeding. In this group, food was not routinely weighed. Seven centers reported using modified house diets. Five served three meals and snacks, two reported continuous (on demand) feeding and one center reported weighing foods routinely. No relationship between type of food service and hours of meal service became apparent, although three meals and snacks were most frequently reported by all types of food service (eight of fifteen). Two centers reported weighing foods for patient consumption on a routine basis. Nine of the fifteen centers responding reported that Nursing personnel delivered the food to the patients' rooms, one unit reported that the cooks delivered food directly to the rooms and one reported that diet technicians delivered trays to the rooms.

The average length of patient stay and type of diet was compared to determine if diet type was associated with length of stay (table 12). 
Table 12

Comparison of Average Length of

patient stay and Type of Diet

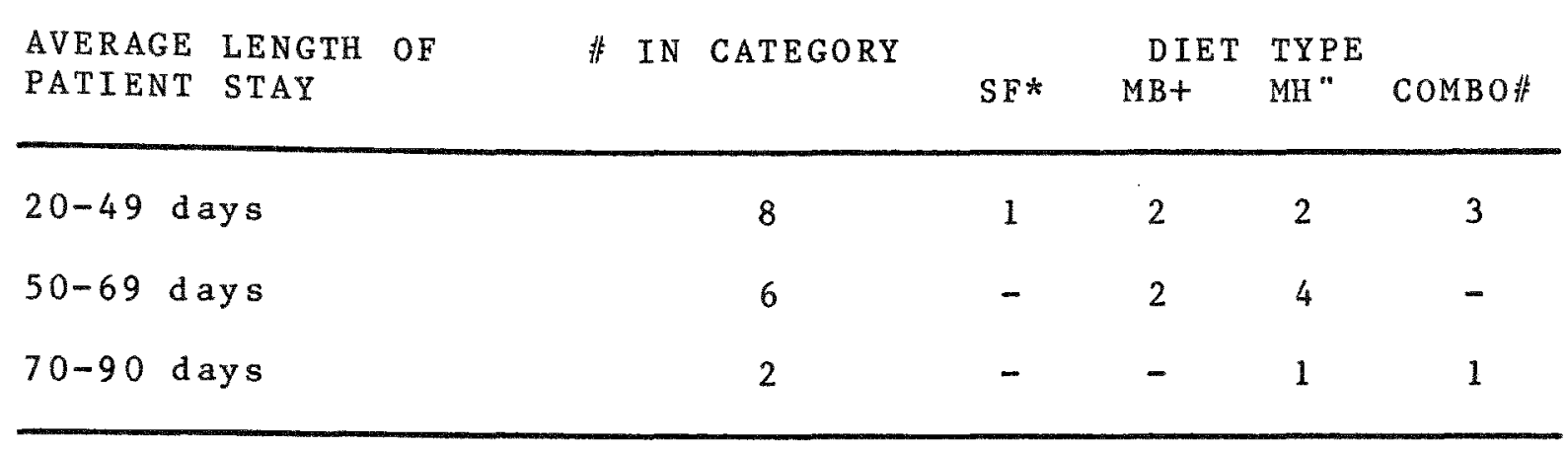

* $S F=$ sterile food service

$+M B=$ modified bacteria means either a low or reduced bacteria diet.

" $\mathrm{MH}=$ modified house means a house diet without fresh vegetables and/or fruits.

\# Сомво = usage of any two of the above diets in one center. 
Eight centers reported average length of stay (LOS) within a range of 20-49 days. Of these eight, one used a sterile food service, three used combination diets, two used modified bacteria diets and two used modified house diets. In the 50-69 LOS group, two used a modified bacteria diet and four used a modified house diet. In the 70-90 day Los range, one center reported using a combination diet and one listed a nodified house diet. No direct relationship was found between average length of stay and type of diet used.

The similarities in the organization and size of medical nutrition services provided at BMT centers were also described. The first item compared was the size of the unit with the existence of separate full-time-equivalents (FTE's) dietitians to cover the BMT patients and scheduling of those dietitians $(\operatorname{tab} 1 \mathrm{e} 13):$ 
Table 13.

Comparison of Number of Beds, Existence of Separate FTE's and Scheduling of Dietitians (R.D.'s)

\begin{tabular}{|c|c|c|c|c|c|c|c|}
\hline \multirow[t]{2}{*}{ BEDS } & \multirow[t]{2}{*}{ IN } & \multirow[t]{2}{*}{ CATEGORY } & \multirow{2}{*}{$\begin{array}{l}\text { SEPARATE } \\
\text { R.D.* }\end{array}$} & \multirow[b]{2}{*}{ \#F TE } & \multicolumn{2}{|c|}{ SCHEDULE } & \multirow[b]{2}{*}{ Mon-Sat } \\
\hline & & & & & $7 \mathrm{days}$ & Mon-Frit & \\
\hline $1-5$ & & $6 "$ & 1 & $1 / 2$ & - & 4 & - \\
\hline $6-10$ & & 5 & - & - & 3 & 1 & - \\
\hline over 10 & & 6 & $\mathrm{va}$ & riable & 1 & 4 & 1 \\
\hline
\end{tabular}

* separate R.D. means a dietition was employed to work exclusively with the BMT patients.

+ Mon-Fri was usually reported with "on call" weekends.

" one center did not report. 
In the six centers that reported one to five beds, one employed a $1 / 2$ FTE to work exclusively with the BMT patients. All centers reporting in this group 1 isted a schedule of Monday through Friday (usually with "on call" weekends). No separate FTE's were listed for the five centers with beds ranging from six to ten. Three of the five listed coverage seven days a week and one reported coverage Monday through Friday. Three of six centers with beds over ten, used separate FTE's for the BMT unit. Number of FTE's were variable, as were the schedules. The most frequently reported schedule was Monday through Friday for both the one to five beds and over ten bed catagories. Three of the four centers that employed dietitians to work exclusively with the BMT patients had over ten beds in the unit. If there was not a specialized dietitian, the percentage of time spent with these patients was variable but the usual range for all sized centers was $10-25 \%$.

The type of food service was also compared to extent of dietitian coverage (table 14): 
Table 14

Comparison of Type of Food Service and

Extent of Dietitian's Coverage in BMT Units

\begin{tabular}{|c|c|c|c|c|c|c|c|c|}
\hline \multirow[t]{2}{*}{ DIET TYPE } & \multirow{2}{*}{$\begin{array}{c}\text { IN } \\
\text { CATEGORY }\end{array}$} & \multirow[t]{2}{*}{ SEPARATE } & \multirow[t]{2}{*}{ R.D.* } & \multirow[t]{2}{*}{ \# FTE } & \multirow[b]{2}{*}{7} & \multicolumn{3}{|c|}{ SCHEDULE } \\
\hline & & & & & & DAYS & $M-F$ & $\mathrm{M}-\mathrm{Sat}$ \\
\hline $\mathrm{SF}+$ & 1 & 1 & & 2 & & - & - & 1 \\
\hline $\mathrm{MB} "$ & 8 & 1 & & 0.5 & & 1 & 6 & - \\
\hline $\mathrm{MH}^{\prime}$ & 7 & 1 & & - & & 1 & 4 & - \\
\hline COMBO\# & 3 & 1 & & 6.75 & & 2 & 1 & - \\
\hline
\end{tabular}

* separate R.D. means a dietitian was employed to work exclusively with the BMT patients.

$+S F=$ sterile food service

" $M B$ = modified bacteria means either a low or reduced bacteria diet.

- MH - modified house means a house diet without fresh vegetables and/or fruit.

\# COMBO - usage of any two of the above diets in one center. 
The center with sterile food service employed two FTE's who worked Monday-Saturday. One of the three units using combination diets (sterile diet plus either a modified bacteria or modified house diet) had 6.75 FTE's. Two centers had a seven day schedule and one reported $M-F$. of the eight centers using modified bacteria diets, one center employed $1 / 2$ FTE, and one center used a seven day coverage while six used Monday-Friday coverage. One of seven centers with modified house diets employed one FTE. Four centers had dietitian coverage Monday through Friday, and one center had seven day/week coverage. There was no evidence of a relationship between type of food service and presence of a specialized dietitian, as each diet type was equally represented. That is, in each diet type, one center each reported the existence of a separate FTE to cover the BMT unit.

The respondents were asked to check specific dietitian services in particular patient treatment categories (see Appendix for original table of results). This indicated when the dietitian's services were most frequently employed. Table 15 1ists the incidence of $R$. D. services in various treatment categories: 
of a total of 510 incidences of dietitian services, 32 (6\%) were done at preadmission. On admission to the hospital, $136(27 \%)$ incidences were reported. One hundred thirty two ( $26 \%$ ) were reported as occuring during critical care monitoring (status post transplantation). In the rehabilitation phase of the treatment, $60(11 \%)$ incidences of services were 1 isted. Discharge planning, outpatient and longterm followup services were reported as follows, respective1y: $74(15 \%), 59(12 \%), 17$ (3\%). Patient-related services of the dietitian were most concentrated on admission and during critical care monitoring. Three centers Iisted longterm followup by the dietitian. The Total Parenteral Nutrition (TPN) ordering was done primarily by the dietitian as a member of a nutrition support team.

Two centers out of 16 charged for outpatient nutrition services rendered. Three centers charged for inpatient services through a nutrition support or TPN team. The rest did not charge for either in-or out-patient services.

An expressed need to standardize services for cost effectivness and efficiency by the dietitians working in these units was determined. One respondent remarked that since there were differences in physician philosophies, standardization among different units may not be posible. One respondent answered "possibly". Seventeen of the 19 respondents answered "yes" to the question, "Would you favor the formation of a network for developing standards for food and/or nutrition 
services?". This strongly suggested that almost all dietitians working with BMT patients wish to form such a network, and that there was a need for standardization of services.

The research question, "Can a model be established from existing BMT centers to build/implement food and nutrition services for a new center?" was answered negatively. As the results illustrate, there were many differences between centers, regardless of grouping categories. It appears that, until there are more reliable studies on actual characteristics of the food, preparation, delivery systems, etc. it will be up to the house staff's particular philosophies which methods of food and nutrition services will be most cost-efficient for their patients.

\section{SUMMARY}

Similarities in organization and size of the food service systems reported are summaried as follows: Most centers ( 16 of 20) used either laminar air flow and isolation rooms or standard isolation rooms only. The newer centers (1975-1983) generally used either a modified bacteria diet (1ow or reduced bacteria) or a modified house diet (without fresh vegetables and/or fruits). The most frequently reported problems when establishing the food/nutrition service were associated with sterile food service. Four of sixteen centers changed from a sterile food service to a more liberal diet at one point in their operation. Comparing type of diet to both number and 
type of beds indicated that the modified bacteria or modified house diet was most frequently used. The food groups most frequently 1 isted in all diet types as well accepted by the patients were meats, breads, and beverages. No evident relationship was found between the type of diet and hours of meal service. The three meals and snacks were the most frequently reported ( 8 of 15 ). Food was routinely weighed in 2 of the 15 centers reporting. No pattern was evident between average length of patient stay and type of diet used.

The similarities in organization and size of the medical nutrition services reported were: the centers with over ten beds most frequently reported employing separate FTE's (registered dietitians) to work with the BMT patients. Scheduling was variable. However, Monday-Friday with "on call" weekends for the dietitian was most frequently reported for all ( 9 of 13). No similarities were found between type of diet and existence of a separate FTE (R.D.). For those centers without separate FTE's percentage of time spent with BMT patients was variable. Incidence of patient-related services of the registered dietitian were most concentrated on admission and during critical care monitoring. Sixteen of nineteen centers reported not charging for either in- or out-patient nutrition services. There was an expressed desire by almost all of the respondents to form a network for developing standards for food and/or nutrition services rendered. 


\author{
CHAPTER V \\ CONCLUSIONS AND RECOMMENDATIONS
}

CONCLUSIONS

This chapter describes conclusions and recommendations derived from data results. A brief sumary of the significant findings follows.

The results of this study indicated a definite trend away from sterile food service. Existing centers report a tendency to use more liberal diet types. The most important problems associated with sterile diets included cost, palatability of foods, and availability of sterile commercial food items. There was no pattern found between average length of patient stay and type of food service. It is not know to what extent the diet played in the rate of recovery for these transplantation patients. It appeared that use of sterile food service might not have been cost effective in the treatment of these patients.

Cost effectiveness is a major factor in current health care considerations, owing largely to the implementation of DRG's. There is little data available for institutions now depending on protocols for food and nutrition services for new bone marrow transplant units.

For the new center being constructed at Miami Children's Hospltal, it is indicated that for the initial two-bed capacity 
unit, a modified bacteria diet would be appropriate and cost effective according to the data from existing centers.

Since deliberations for pediatric DRG's are in progress, it is important to know the time and extent of R.D. services in relation to this DRG of bone marrow transplantations. BMT's are currently reimbursed at a substantially lower rate than the actual cost of such a procedure.

It is evident that an information network is desired by the R.D.'s working in these settings. 


\section{RE COMMENDATIONS}

The results of this study on food and nutrition services at bone marrow transplant (BMT) centers can serve as a basis for recommendations in two specific areas: future research in cost effectiveness of services and the quality of foods served in different diet types.

Further studies need to be done on the actual cost of each type of diet used with BMT patients. Concurrent with pricing studies, more specific research of nutritional/medical factors affecting patient length of stay and diet types would help define cost effectiveness.

A more adequate description of specific foods and preparation methods of these special diets are needed to make valid comparisions.

Food intake comparisons of patients consuming different diet types would also be useful. Nutrient retention in sterilized or autoclaved foods requires more study. The purpose of weighing foods needs clarification. DRG's currently ignore nutrition intervention related to medical treatment. Dietitians can document their effectiveness by charging for services rendered. Justification through charging for services can be accomplished currently in pediatric hospitals wherein DRG's are exempt. Ultimately, 
charging and reimbursement information may pave the way for adjusting reimbursement fees. Dietitians need to evaluate their time spent with these patients. It may be that developing an effective outpatient counseling service could result in better and more easily justified nutritional care. 
APPENDIX 
February 4,1985

Dear Colleague,

The Hematology/Oncology Department at Miami Children's Hospital is developing a marrow transplant unit in a new facility adjacent to our hospital. I have taken this opportunity in the workplace to develop a food and nutrition service research project as part of the requirements for a Master of Science in Dietetics and Nutrition at Florida International University. As you know, the unique nature of food service management in maxrow transplant units as well as the potential length and breadth of nutritional assessment and monitoring is a new and developing field.

The accompanying questionnaire is being sent to all marrow transplant centers in the United States. The purpose of this survey is to gather information from existing centers and develop a model protocol for our unit.

I would be very appreciative if you would take the time to answer this survey. Your experience with these specialized patients will be very valuable to our center and to my thesis project. The number on the top of the questionnaire will be used only for coding and if clarification of response is necessary. Identities will remain anonymous; data will be grouped according to number of beds in the unit. If you are interest, a summary of the results will be sent to you.

With sincere thanks for your time and cooperation.

/s/ Amy Dezenhal1

Amy Dezenha11, R.D.

Chief Dietitian

/s/ Katherine Curry

Katherine Curry, Ph.D., R.D.

Director of Thesis

$A D / a b$

ENCLOSED 


\section{BACKGROUND INEORMATION}

the Center is associated with: Hospital ther (please explain)

University both free-standing

lumber of beds in the unit - Usual census - Average length of stay ype and number of rooms: Laminar Air Flow Life Is 1 and Standard Isolation ther (please explain) ypes of patient disease states treated: Leukemia Aplastic Anemia Severemunodeficiency disease syndroms other (please explain)

hen were marrow transplants first performed in your center? 19 Could you hare any problems encountered whe the food/nutrition service was developed?

- FOOD SERVICE

ype of food service: Sterile diet_Low bacteria diet_ Reduced bacteria diet tandard hose diet___ Please describe diet checked or send copy

s there a research kitchen separate from the main (hospital) food service? es_no_- If yes, how many cooks per shift? - How many shifts? o the cooks have special training" Yes__no____ If yes, could you briefly escribe what the training is and where it is received?

ow frequently is inservice education of the cooks repeated? re audits conducted to document standardized techniques? yes hat is the procedure for bacteriologic monitoring of foods? If there is a ritten policy, please enclose

f you have any menus to share, please enclose!!

LEASE RETURN TO: AMY DEZENHALL, R.D., MIAMI CHILDREN'S HOSPITAL, 6125 SW 31 STREET, MIAMI, FLORIDA, 33155 
Please list thoses foods particularly well accepted by the patients. Include brand names whe applicable:

Autoclabed:

We11-Cooked:

Prepackaged or canned:

According to your Center's diet(s), please answer the following in the appropriate colums:

$\begin{array}{llll}\begin{array}{l}\text { Hours of } \\ \text { meal service }\end{array} & \begin{array}{l}\text { \# trays served food weighed How is food } \\ \text { per day }\end{array} & \begin{array}{l}\text { before serving delivered? } \\ (y \text { or } n)\end{array} & \begin{array}{l}\text { Explain. } \\ \hline\end{array}\end{array}$

Sterile

diet

Low

Bacteria

Diet

Reduced

Bacteria

diet

Standard

house diet 


\section{NUTRITION SERVICES, Continued}

Ire there dietitians who work exclusively with the marrow transplant patients? ies_no__. If yes, how many FTE's are employed?_. What is the role of the 3.D. on the transplant unit? Please describe or attach a job description

loes the R.D. cover the marrow transplant unit: 7 days per week Monday iriday other

f there is no specialized dietitian, what percent of the R.D.'s time is spent ith these patients per day? ervices rendered (please specify) Inpatient outpatient

ould you favor the formation of a network for developing standards for food nd/or nutrition services? yes no

f you are interested in a sumary of the results of this survey, please provide our name and address:

LEASE RETURN TO: AMY DEZENHALL, R.D. MIAMI CHILDREN'S HOSPITAL, 6125 SW 31 STREET, MIAMI, FLORIDA, 33155 
Qlease check below: daily, patient-related responsibilities of the R.D. with the marrow transplant patient

\begin{tabular}{|c|c|c|c|c|c|c|c|}
\hline & $\begin{array}{l}\text { PRE } \\
\text { ADMISSION } \\
\end{array}$ & $\begin{array}{l}\text { ON } \\
\text { ADMISSION } \\
\end{array}$ & $\begin{array}{l}\text { CRITICAL CARE } \\
\text { MONITORING } \\
\end{array}$ & $\begin{array}{l}\text { REHABIL- } \\
\text { ITATION } \\
\end{array}$ & $\begin{array}{l}\text { DISCHARGE } \\
\text { PLANN ING } \\
\end{array}$ & $\begin{array}{l}\text { OUT- } \\
\text { PATIENT }\end{array}$ & $\begin{array}{l}\text { LONG-TERM } \\
\text { FOLLOW UP }\end{array}$ \\
\hline Weight/height & 4 & 12 & 10 & 7 & 7 & 6 & 2 \\
\hline $\begin{array}{l}\text { MAC, MAMC, TSF } \\
\text { (anthroponetrics) }\end{array}$ & 4 & 9 & 4 & 1 & 2 & 4 & 1 \\
\hline Diet history & 5 & 13 & 1 & & 1 & 4 & 1 \\
\hline $\begin{array}{l}\text { Jutrient intake } \\
\text { analysis }\end{array}$ & 3 & 8 & 11 & 8 & 8 & 5 & 1 \\
\hline $\begin{array}{l}\text { Complete nutr. } \\
\text { Assessment }\end{array}$ & 1 & 13 & 7 & 3 & 3 & 4 & 3 \\
\hline $\begin{array}{l}\text { Document in } \\
\text { medical record }\end{array}$ & 3 & 15 & 14 & 5 & 8 & 5 & 2 \\
\hline $\begin{array}{l}\text { Medical rounds } \\
\text { with M.D.'s }\end{array}$ & & 7 & 14 & 6 & 4 & 3 & \\
\hline $\begin{array}{l}\text { Supplement } \\
\text { recommendation }\end{array}$ & 3 & 10 & 12 & 7 & 7 & 6 & 1 \\
\hline $\begin{array}{l}\text { Recommend energy } \\
\text { requirements }\end{array}$ & 2 & 13 & 12 & 4 & 7 & 4 & 2 \\
\hline $\begin{array}{l}\text { Patient/parent } \\
\text { counseling }\end{array}$ & 3 & 9 & 6 & 6 & 10 & 6 & 2 \\
\hline $\begin{array}{l}\text { Input/output } \\
\text { monitoring }\end{array}$ & & 6 & 11 & 4 & 4 & 4 & \\
\hline $\begin{array}{l}\text { TPN } \\
\text { recommendations }\end{array}$ & 1 & 11 & 14 & 3 & 5 & 4 & 2 \\
\hline $\begin{array}{l}\text { TPN } \\
\text { ordering }\end{array}$ & 1 & 4 & 4 & 2 & 4 & 1 & \\
\hline $\begin{array}{l}\text { TPN } \\
\text { monitoring }\end{array}$ & & 6 & 12 & 5 & 4 & 3 & \\
\hline TOTAL & 32 & 136 & 132 & 60 & 74 & 59 & $17=510$ \\
\hline
\end{tabular}




\section{SELECTED REFERENCES}

Aker, Saundra N. "On the Cutting Edge of Dietetic Services". Nutrition Today 19 (July/August 1984): 24-27.

Aker, Saundra N., et. al., "Nutritional support in Marrow Graft Recipients with Single versus Double Lumen Right Atrial Catheters" "Experimental Hematology 10 (October 1982): $732-\overline{737 .}$

Aker, Saundra N., Cheney, Carrie L. "The use of sterile and Low Microbial Diets in Ultraisolation Environments". Journal of enteral and parenteral Nutrition 7 (July/August 1983): 390-396.

Aker, Saundra N., Lenssen, Polly, et. al. "Nutritional Assessment in the Marrow Transplant Patient". Nutritional Support Services 3 (october 1983): 22-24.

Bailey, Kenneth D. Methods of Social Research, 2nd ed. New York: The Free Press, 1982.

Cunningham, Beth Ann, Lenssen, Polly, Aker, Saundra, et. al. "Nutritional Considerations During Marrow Transplantation" Nursing Clinics of North America 18 (September 1983): 585-595.

Hutchinson, Margaret McGahan, Itoh, Kathleen. "Nursing Care of the Patient Undergoing Bone Marrow Transplantation for Acute Leukemia" Nursing Clinics of North America 19 (December 1982): 6⿸丆口7-711.

Johnson, F.L., Look, A.T., et. al. "Marrow Transplantation for Sickle Cel1 Anemia" Blood 62 Supplement 1 (November 1983): $223 a$.

Johnson, F.L., Thomas, E.D., Clark, B.S., et. al. "A Comparison of Marrow Transplantation with Chemotherapy for Children Acute Lymphoblastic Leukemia in Second or Subsequent Remission" New England Journal of Medicine $305(1981): 846-851$.

Lenssen, Polly, et. a1. "Parenteral Nutrition in Bone Marrow Transplant Recipients After Discharge from the Hospital" Experimental Hematology (November 1983): $974-981$.

Pizzo, P.A., Purvis, D.S., Waters, C. "Microbiological Evaluation of Food Items". Journal of the American Dietetic Association 81 (September 1982): 272-279. 
Punch, L. "DRG's + Complex Caseload = Trouble for Children's Hospitals" Modern Healthcare (October 1984: 62-66.

Stream, Patricia "Functions of the Outpatient Clinic Before and After Marrow Transplantation" Nurisng Clinics of North America 18 (September 1983): 597-610.

Stuart, Rober K., Sensenbrenner, Lyle L. "Adverse Effects of Nutritional Deprivation on Transplanted Hematopoietic Ce11s". Experimental hematology (September 1979): 435-442.

The American Dietetic Association. "Work Begins on DRG"s for Pediatric Care." ADA Courier (September/October 1984): 8.

Thomas, E.D. "The Role of Marrow Transplantation in the Eradication of Malignant Disease". Cancer 49 (September 1982): 1963-1969.

Thomas, E.D. "The Use and Potential of Bone Marrow Allograft and Whole Body Irradiation in the Treatment of Leukemia". Cancer 50 (October 1982): 1449-1454. 
VITAE

Title: Food and Nutrition Services in Bone Marrow Transplant Centers.

Nane: Amy Dezenhall,M.S.,R.D.

Place,

Date of

Birth: Philadelphia, Pennsylvania. 1957.

University: Florida International University

1978-1980 Bachelor of Science in Dietetics and Nutrition 1983-1985 Master of Science in Dietetics and Nutrition

Current

Employment: Chief Dietitian, Miami Children's Hospital, Miami, Florida.

Membership: American Dietetic Association, Miami Dietetic Association, A.S.P.E.N. 